\title{
PENDAMPINGAN DALAM RANGKA MENINGKATKAN KETERAMPILAN PEMBUATAN SERBUK JAMU INSTAN UNTUK PENJUAL JAMU GENDONG DI WILAYAH KELURAHAN SEMEMI KECAMATAN BENOWO SURABAYA
}

\author{
Oleh \\ Suyatno, Sri Hidayati Syarief, Nurul Hidayati, dan Tukiran ${ }^{*}$
}

\begin{abstract}
Abstrak
Telah dilakukan kegiatan Pengabdian Kepada Masyarakat (PKM) kepada penjual jamu gendong sebagai peserta di wilayah kelurahan Sememi, kecamatan Benowo, Surabaya. Kegiatan PKM ini ditujukan untuk melatih keterampilan peserta dalam pembuatan serbuk jamu instan. Kegiatan ini diharapkan bermanfaat untuk meningkatkan ketrampilan peserta dalam membuat serbuk jamu instan serta meningkatkan taraf ekomoni keluarganya. Pendekatan yang digunakan dalam PKM ini adalah pendekatan partisipasif, sedangkan metode yang diterapkan dalam pendampingan adalah metode pembelajaran orang dewasa (andragogi). Kegiatan ini telah dilaksanakan pada hari Rabu, tanggal 9 Oktober 2014 di ruang Balai RT 03 RW 01 kelurahan Sememi, kecamatan Benowo, Surabaya dan diikuti oleh 21 orang peserta. Berdasarkan hasil analisis kegiatan di lapangan dan angket dapat disimpulkan bahwa kegiatan pelatihan yang dilakukan mendapatkan respon yang positif dari peserta serta telah mampu meningkatkan pengetahuan dan keterampilannya, khususnya dalam pembuatan serbuk jamu instan.
\end{abstract}

Kata kunci: Penjual jamu gendong, serbuk jamu instan, jahe, kunyit putih

\begin{abstract}
It had conducted the community services activity to the herbalists in the Sememi village, Benowo, Surabaya. This activity was intended to train the herbalists in preparing the instant herbal powders. This activity was expected to be useful for improving skills in preparing the instant herbal powders and to improve the family income. The approach used in this activity was the participatory approach, whereas the methods applied in mentoring was the adult learning method (andragogy). This activity was held on Wednesday, October 9, 2014 in the meeting room of RT 03 RW 01, Sememi village, Benowo, Surabaya and followed by the twenty one herbalists. Based on the analysis of activity in the field and the questionnaire could be concluded that the training activity obtained a positive response from the herbalists and able to improve their knowledge and skills in preparing the instant herbal powders.
\end{abstract}

Keywords: Herbalists, instant herbal powders, ginger, white turmeric

\section{PENDAHULUAN}

Negara Indonesia merupakan salah satu negara yang memiliki keanekaragaman kekayaan alam hayati (biodiversity). Salah satu kekayaan alam hayati tersebut berupa beranekaragam spesies tumbuhan, mulai dari tumbuhan tingkat rendah hingga tumbuhan tingkat tinggi.
Tumbuhan dapat dipandang sebagai reservoir bahan-bahan kimia karena mampu memproduksi senyawa metabolit sekunder. Senyawa kimia tersebut selanjutnya terbukti memiliki aktivitas biologis yang dapat dimanfaatkan sebagai bahan obatobatan dan bahan agrokimia (Achmad, dkk., 2007; Heyne, 1987; Robinson,

\footnotetext{
*) Dosen di Jurusan Kimia, Fakultas MIPA, Unesa
} 
1991; Manitto, 1992). Menurut Handra (2005), di Indonesia terdapat sekitar 30.000 spesies tanaman yang sebagian besar tersebar di wilayah hutan hujan tropis. Dari spesies tanaman tersebut, lebih dari 3300 spesies (11\%) merupakan tanaman yang mempunyai khasiat obat dan baru sekitar 300 spesies yang telah dimanfaatkan oleh masyarakat yang berupa obat tradisional atau jamu.

Akhir-akhir ini pemanfaatan tumbuhan sebagai bahan obat tradisional semakin meningkat karena semakin mahalnya obat sintetik serta besarnya efek samping yang ditimbulkan. Banyak jenis produk obat herbal yang beredar di pasaran dan dimanfaatkan oleh masyarakat, mulai dari jenis jamu, obat herbal terstandart $(\mathrm{OHT})$, serta fitofarmaka. Jamu merupakan jenis obat herbal yang paling banyak dikonsumsi masyarakat. Disamping itu sebagian besar masyarakat menyiapkan sendiri obat herbal dari tumbuhan obat keluarga (TOGA) yang ditanam di sekitar rumahnya (Suyatno, 2011).

Salah satu produk herbal yang telah dikenal masyarakat adalah jamu instan. Beberapa contoh produk serbuk jamu instan disajikan pada Gambar 1. Produk tersebut berbentuk serbuk sehingga bersifat praktis dan cepat dalam penyajiannya, serta memiliki daya simpan yang relatif lama. Jamu instan dibuat dengan menggunakan ekstrak tumbuhan obat yang banyak ditanam di sekitar rumah atau lebih dikenal dengan TOGA. Contoh TOGA yang banyak digunakan untuk memproduksi serbuk jamu instan adalah kunyit, kunyit putih, jahe, temulawak, dan temu mangga. Namun demikian tidak tertutup kemungkinan untuk membuat serbuk jamu instan menggunakan tanaman obat yang lain, misalnya daun pegagan (Angria, 2013; Anonim, 2013).

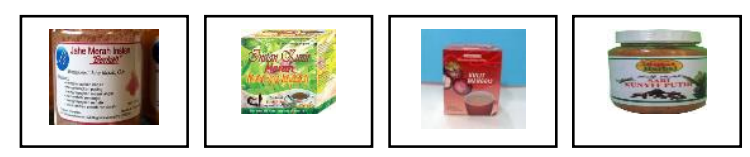

Gambar 1. Beberapa Contoh Produk Serbuk Jamu Instan: (a) Jahe merah

(b) Kunir merah, (c). Kulit manggis (d) Kunyit putih

Kelurahan Sememi merupakan salah satu kelurahan yang berada di Kecamatan Benowo Surabaya. Warga di kelurahan tersebut hidup dari sektor pertanian, perkebunan, perikanan, industri, perdagangan, dan jasa. Mata pencaharian warga terdiri dari petani, pegawai di sektor jasa/ perdagangan, pegawai di sektor industri, serta wirausaha. Salah satu jenis wirausaha yang menjadi mata pencaharian warga kelurahan Sememi adalah penjual jamu gendong.

Di kelurahan Sememi terdapat sekitar 20 penjual jamu gendong yang tersebar di sepuluh Rukun Warga (RW). Produk jamu yang dijual berupa jamu rebusan atau godogan. Jamu yang dijual rata-rata adalah beras kencur, cabe puyang, temu kunci, kunyit asam, sirih, pahitan, dan sinom. Mengingat bentuknya rebusan maka harga jamu tersebut relatif murah. Harga satu gelas jamu dengan volume sekitar $200 \mathrm{~mL}$ adalah 1000 rupiah. Dalam sehari rata-rata dapat terjual 10 botol jamu yang harga per botolnya Rp. 
8000. Jika dikurangi biaya produksinya maka keuntungan rata-rata per harinya sekitar Rp. 50.000. Dengan demikian keuntungan yang diperoleh tidak terlalu besar; hanya cukup untuk mencukupi kebutuhan hidup sehari-hari sehingga kurang mampu meningkatkan tingkat ekonomi secara signifikan.

Rendahnya pendapatan penjual jamu gendong juga disebabkan oleh kuantitas produk yang dijual per harinya relatif rendah. Setiap penjual jamu gendong rata-rata menjajakan 10 botol jamu dengan volume 1,5 Liter. Di lihat dari aspek manajemen, tata kelola yang sederhana, dan terkesan apa adanya juga ikut menunjang stagnasi usaha dan tidak berkembangnya usaha ke arah yang lebih baik dan menjanjikan. Faktor cuaca sangat berpengaruh terhadap hasil penjualan. Dalam kondisi cuaca panas maka jamu tersebut cepat habis terjual dan sebaliknya jika cuaca hujan maka sangat sulit untuk menjual habis jamu tersebut. Sisa jamu yang tidak terjual tersebut biasanya dibagikan ke tetangga atau dibuang karena tidak bertahan lama.

Berdasarkan hasil wawancara kami dengan warga penjual jamu gendong diperoleh informasi bahwa mereka belum berpengalaman membuat jamu instan berbentuk serbuk. Jamu instan dalam bentuk serbuk tentu memiliki masa simpan yang lebih lama dibandingkan jamu rebusan karena kadar airnya sangat rendah. Dengan demikian distribusi produk serbuk jamu instan jauh lebih luas sehingga keuntungan yang diperoleh akan lebih besar. Di samping itu kepraktisan dalam penggunaan serbuk jamu instan akan meningkatkan jumlah konsumen produk tersebut. Banyaknya warung, toko jamu, dan toko obat yang berada di wilayah Kelurahan Sememi sangat mendukung penjualan produk serbuk jamu instan. Oleh karena itu dalam rangka membantu pemerintah, khususnya Pemkot Surabaya maka kami bermaksud memberikan pendampingan dan pelatihan kepada penjual jamu gendong di wilayah kelurahan Sememi Kecamatan Benowo Surabaya untuk meningkatkan keterampilannya dalam pembuatan serbuk jamu instan yang hasilnya dapat dikomersialkan untuk meningkatkan kemandirian dan kesejahteraannya.

\section{METODE PELAKSANAAN}

\section{Pemecahan Masalah}

Metode pendekatan yang ditawarkan dan digunakan dalam pendampingan dan pelatihan tentang pembuatan serbuk jamu instan di Kelurahan Sememi Kecamatan Benowo Surabaya adalah pendekatan partisipatif. Pendekatan ini meliputi konseptual/teori, penghayatan pengalaman, pemaparan (memadukan konsep dengan lapangan, penyimpulan, dan penerapan) dengan berorientasi pada materi pelatihan, melalui metode diskusi dan workshop. Metode yang digunakan pada proses pendampingan dan pelatihan ini adalah metode andragogi atau metode pembelajaran orang dewasa. Efektivitas dan optimalisasi proses pendampingan dan pelatihan dalam diskusi dan workshop mendorong dan memfasilitasi proses sharing dan interaksi aktif dengan para peserta pelatihan. 
2. Khalayak Sasaran antara yang Strategis

Sasaran kegiatan pengabdian kepada masyarakat ini adalah para penjual jamu gendong yang berdomisili di wilayah kelurahan Sememi Kecamatan Benowo Surabaya. Jumlah penjual jamu gendong yang dilibatkan dalam kegiatan ini sebanyak 21 orang yang sebagian besar merupakan ibuibu.

\section{Keterkaitan}

Para penjual jamu gendong di wilayah Kelurahan Sememi Kecamatan Benowo Surabaya rata-rata memiliki taraf ekonomi yang kurang. Penghasilan yang diperoleh dari penjualan jamu hanya mampu digunakan untuk menutup kebutuhan hidupnya seharihari. Oleh karena itu berbagai jenis pelatihan, termasuk kegiatan pelatihan pembuatan serbuk jamu instan ini sangat relevan dilakukan dalam upaya untuk meningkatkan taraf ekonomi keluarganya.

\section{Metode Kegiatan}

Solusi yang ditawarkan dalam proses pendampingan dan pelatihan pembuatan jamu instan menggunakan tanaman TOGA untuk membekali keterampilan para penjual jamu gendong di wilayah kelurahan Sememi Kecamatan Benowo Surabaya adalah sebagai berikut:

a. Membuat atau menyiapkan buku panduan pembuatan serbuk jamu instan

b. Memberikan contoh pembuatan serbuk jamu instan dengan melibatkan peserta pelatihan menggunakan bahan-bahan yang telah disediakan

c. Praktek mandiri pembuatan serbuk jamu instan yang dilakukan oleh penjual jamu gendong peserta pelatihan,

d. Melakukan refleksi/umpan balik dan masukan/opini/pendapat dan saran mereka tentang hasil pelatihan yang telah dilaksanakan,

e. Melakukan monitoring dan evaluasi terhadap pelaksanaan pelatihan dan diikuti pemberian lembar angket yang berhubungan dengan proses pendampingan dan pelatihan yang telah dilakukan.

\section{HASIL DAN PEMBAHASAN}

Kegiatan PKM pelatihan pembuatan serbuk jamu instan bagi para penjual jamu gendong yang berdomisili di wilayah kelurahan Sememi Kecamatan Benowo Surabaya dilaksanakan melalui beberapa tahap yang dapat diuraikan sebagai berikut.

\section{Tahap Persiapan}

Pada tahap ini tim PKM melakukan pendekatan dan wawancara dengan kelompok penjual jamu gendong yang berdomisili di kelurahan Sememi, kecamatan Benowo, Surabaya. Dari kegiatan tersebut banyak diperoleh informasi yang berkaitan dengan jenis jamu gendong yang dipasarkan, keuntungan yang diperoleh, serta kendala yang dihadapi dalam melakukan penjualan jamu gendong. Para penjual jamu gendong menyambut baik tawaran Tim PKM untuk melakukan 
pelatihan pembuatan serbuk jamu instan karena mereka belum mampu membuat dan memiliki prospek untuk dapat menambah penghasilannya. Selanjutnya Tim PKM mengajukan surat permohonan kepada Ketua RT 03 RW 01 kelurahan Sememi, untuk melaksanakan kegiatan PKM di Balai RT 03 RW 01 kelurahan Sememi.

Tim PKM mempersiapkan peralatan dan bahan yang diperlukan untuk kegiatan pelatihan, seperti wajan, kompor gas, pengaduk kayu, saringan, panci, blender, rimpang kunyit putih, dan rimpang jahe. Di samping itu tim juga menyiapkan handout untuk pembuatan serbuk jamu instan serta angket untuk mengetahui respon peserta terhadap kegiatan pelatihan yang dilaksanakan.

\section{Tahap Pelaksanaan}

Berdasarkan kesepakatan antara para penjual jamu gendong dan Tim PKM, maka kegiatan PKM dilaksanakan pada hari Kamis tanggal Rabu, 8 Oktober 2014. Kegiatan dimulai pukul $13.00-17.00$ WIB, bertempat di Balai RT 03 RW 01 Kelurahan Sememi Kec Benowo Surabaya. Sebanyak 21 orang penjual jamu gendong tersebut sangat antusias mengikuti kegiatan tersebut.

Kegiatan PKM ini diawali dengan penjelasan materi pelatihan pembuatan serbuk jamu instan serta aspek wirausahanya oleh Tim PKM. Pada akhir penyajian dilakukan tanya jawab dan terlihat bahwa peserta sangat antusias dalam bertanya, baik cara pembuatan, cara mengemas, jenis pengemas yang baik, khasiat, aspek ekonomi, dan batas kedaluwarsanya.

Selanjutnya peserta dibagi menjadi dua kelompok, yakni kelompok pembuat serbuk jahe instan dan kelompok pembuat serbuk kunyit putih instan. Tim PKM mendampingi masingmasing kelompok sampai dihasilkan serbuk jahe instan dan kunyit putih instan yang siap digunakan. Peserta terlihat sangat bersemangat melakukan pembuatan serbuk jamu instan didampingi oleh Tim PKM.

\section{Tahap Refleksi}

Pada akhir pelatihan, Tim PKM melakukan tanya jawab dengan peserta pelatihan berkaitan dengan kegiatan pembuatan serbuk jamu instan yang telah dilaksanakan. Peserta menunjukkan rasa senang karena telah memiliki keterampilan membuat serbuk jamu instan yang memiliki potensi untuk menambah penghasilan. Untuk menggali respon yang lebih lengkap dan mendalam maka peserta diberi angket yang berisi tanggapan terkait: (1) Alasan mengikuti pelatihan, (2) Sikap keluarga, (3) Penyelenggaraan pelatihan, (4) Ketertarikan terhadap kegiatan, (5) Manfaat kegiatan, (6) Peningkatan pengetahuan, dan keterampilan, (7) Keyakinan hasil pelatihan dapat dilanjutkan di rumah, (8) Apakah pelatihan ini pernah dilakukan, (9) Penyampaian materi oleh narasumber, dan (10) Kesukaan terhadap materi pelatihan. Di samping itu Tim PKM juga menghimpun saran dari peserta untuk diisikan pada bagian akhir angket. 
Berdasarkan analisis hasil angket peserta dapat dinyatakan bahwa $85,7 \%$ peserta mengikuti pelatihan karena ingin menambah keterampilan, 9,5\% karena ingin memperoleh sumbangan, dan 4,8\% karena mengikuti ajakan teman. Semua peserta (100\%) menyatakan bahwa keluarga sangat mendukung keikutsertaannya dalam pelatihan. Berkaitan dengan penyelenggaraan kegiatan pelatihan, $81 \%$ peserta menyatakan sangat baik dan $19 \%$ peserta menyatakan baik. Sebanyak $85,7 \%$ peserta menyatakan kegiatan pelatihan sangat menarik dan $14,3 \%$ peserta menyatakan menarik. Semua peserta (100\%) menyatakan bahwa kegiatan pelatihan ini sangat bermanfaat. Sehubungan dengan peningkatan pengetahuan dan keterampilan, sejumlah $95,2 \%$ peserta menyatakan sangat meningkat dan $4,8 \%$ peserta menyatakan meningkat. Sebanyak $81 \%$ peserta sangat yakin dapat melanjutkan hasil pendampingan ini di rumah, 14,3\% menyatakan yakin, dan $4,8 \%$ kurang yakin karena peralatan di rumah tidak lengkap. Semua peserta $(100 \%)$ menyatakan bahwa pelatihan pembuatan serbuk jamu instan belum pernah dilakukan. Berkaitan dengan materi yang disampaikan narasumber, 85,7\% peserta menyatakan sangat mudah dipahami sedangkan $14,3 \%$ peserta menyatakan mudah dipahami. Semua peserta $(100 \%)$ menyukai kedua materi pelatihan yakni pembuatan serbuk kunyit putih instan dan jahe instan.

Beberapa hal yang disarankan peserta adalah: (1). Perlu dilakukan pendampingan pelatihan menggunakan tanaman TOGA yang lain, (2). Dilakukan pelatihan dengan materi pembuatan jamu herbal jenis yang lain, (3). Dilatih manajemen pemasaran produk hasil pelatihan, (4). Dilatih cara mengemas produk agar memiliki nilai jual, dan (5). Frekwensi pelatihannya ditambah.

Berdasarkan hasil angket tersebut dapat dinyatakan bahwa kegiatan pelatihan yang dilakukan mendapatkan respon yang positif dari para peserta serta telah mampu meningkatkan pengetahuan dan keterampilannya, khususnya dalam pembuatan serbuk jamu instan. Beberapa faktor pendukung terlaksananya kegiatan PKM ini dengan baik antara lain:

a. Tingginya motivasi peserta untuk mengikuti seluruh rangkaian kegiatan.

b. Tingginya antusias dan minat peserta dalam memperhatikan penyajian materi terbukti dengan banyaknya pertanyaan yang diajukan selama proses kegiatan. Pertanyaan yang muncul tidak hanya seputar materi dan teknik pembuatan melainkan lebih luas yakni tentang mengapa kunyit putih berkasiat sebagai antikanker, bagaimana peluang usaha serbuk jamu instan, apakah masih ada prospek yang cerah, bagaimana teknik pemasaran produk tersebut di pasaran, serta bagaimana mengemas produk agar bernilai jual tinggi.

c. Fasilitas yang cukup memadai yang telah disediakan oleh Tim PKM dan Ketua RT 03 RW 01 kelurahan Sememi Kec Benowo Surabaya. 
d. Dukungan penuh dari Pimpinan dan staf RT 03 RW 01 kelurahan Sememi, serta para penjual jamu gendong kelurahan Sememi Kec Benowo Surabaya.

\section{SIMPULAN DAN SARAN}

Berdasarkan hasil pengamatan dan diskusi selama pelatihan, serta analisis angket peserta maka dapat disimpulkan:

1. Para penjual jamu gendong di wilayah kelurahan Sememi, kec Benowo, Surabaya telah memiliki keterampilan dalam pembuatan serbuk jamu instant .

2. Para penjual jamu gendong di wilayah kelurahan Sememi, kec Benowo , Surabaya memberikan respon yang sangat positif terhadap penyelenggaraan kegiatan pelatihan pembuatan serbuk jamu instant.

Berdasarkan kenyataan manfaat dan hasil yang diperoleh, maka disarankan agar dilakukan kegiatan pasca pelatihan, berupa pelatihan teknik pengemasan, manajemen produksi dan pemasaran sehingga produk yang dihasilkan dapat dipasarkan untuk meningkatkan taraf kehidupan para penjual jamu gendong di wilayah kelurahan Sememi, kec Benowo, Surabaya.

\section{DAFTAR PUSTAKA}

Achmad, S.A., Hakim, E.H., Makmur, L, Syah, Y.M,, Juliawaty, L,D, Mujahidin, D. (2007). Ilmu Kimia dan Kegunaan Tumbuh-
Tumbuhan Obat Indonesia. Jilid 1. Bandung: Penerbit ITB.

Angria, M. (2013). Pembuatan Minuman Instan Pegagan (Centella asiatica) dengan Cita Rasa Cassia vera. Padang: Prodi Teknologi Hasil Pertanian.

Anonim. (2013). Jamu Instant Ala Sumarni.

http://kesehatan.kompasiana.com/ alternatif/2012/09/07/jamu-instanala-sumarni-491080.html. Diakses tanggal 10 Januari 2013.

Handra, H. (2005). Jamu Toga dan Apikasinya dalam Rumah Tangga. http://kepegawaian.unpad.ac.id/inf odetail.aspx?id=2. Diakses tanggal 4 Maret 2014.

Heyne K. (1987). Tumbuhan Berguna Indonesia. Jilid 1. Jakarta : Departemen Kehutanan.

Mallaleng, H.R., Purwaningtyas, U., Hermawati, R., Solichah, N., Syah, F.Z.N. (2011). Tanaman Obat untuk Penyakit Sindrom Metabolisme. Malang: UM Press.

Manitto P. (1992). Biosintesis Produk Alami. Cetakan I. Penerjemah Koensoemardiyah. Semarang: IKIP Semarang Press.

Robinson T. (1991). The Organic Constituents of Higher Plants. 6-th Ed. North Amherst, MA : Cordus Press.

Suyatno (2011). Potensi Tumbuhan Paku Indonesia sebagai Bahan Baku Fitofarmaka.

Pidato Pengukuhan Guru Besar. Surabaya: Unesa University Press. 